\title{
Trends In Credit To Smallholder Farmers In South Africa
}

Joseph Chisasa, University of South Africa, South Africa Daniel Makina, University of South Africa, South Africa

\begin{abstract}
Access to credit for smallholder farmers remains a challenge in most developing countries. This paper examines the trend and pattern of bank credit to smallholder farmers in South Africa, both before and after the attainment of democratic government. The analysis of the trend and pattern of bank credit to smallholder farmers was conducted within the confines of the same agricultural sector, across all economy sectors and in relation to GDP. Our analyses show that bank credit to smallholder farmers is (and continues to be) a small fraction of total credit to the private sector and is a very small proportion of GDP. The smallholder farmer sector is observed to face the same constraints to credit as SMEs, a category of enterprises to which they also belong. In light of the importance of agriculture, in general, and smallholder farmers, in particular, to South Africa's poverty alleviation and food security drive, our results have important policy implications.
\end{abstract}

Keywords: Smallholder Farmers; Bank Credit; SMEs, South Africa

\section{INTRODUCTION}

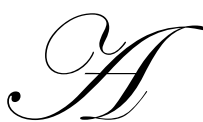
among others, access to finance and ability to employ sound business management principles. The strategic importance of the small to medium size enterprise (SME) sector, in general, and the smallholder farming sector, in particular, has ushered in a growing interest in research on credit risk management in agriculture among other topics (Bandyopandhyay, 2007: 3).

South African agriculture is of a highly dualistic nature where a developed commercial sector co-exists with large numbers of subsistence ${ }^{1}$ (communal) farms. According to Sandrey and Vink (2008: 220), South African commercial farmers have historically been relatively well-advanced in terms of technology, although quite dependent on imported technology, whether through imported machinery and/or agrochemicals, or under license, as is the case for genetically modified (GM) seed. On the other hand, subsistence farms have been less endowed in terms of technology. Prior to 1994, black farmers did not benefit from state support while white farmers were supported by legislation and subsidy. The result was that black farmers tilled small areas of land, with insufficient investment or institutional support (Oettle et al., 1998: 6).

In light of the foregoing, it has been observed that South Africa needs to ensure a healthy agricultural industry that contributes to the country's gross domestic product (GDP), food security, social welfare, job creation and ecotourism, while adding value to raw materials (World Wide Fund for Nature, undated). Smallholder agriculture is increasingly seen to be playing an important role in the economies of many countries. Globally, most governments focus on the smallholder farming sector to enhance economic growth. This is particularly so because the smallholder farming sector is a component of the broader SME sector which is considered to be providing

\footnotetext{
${ }^{1}$ The term subsistence farmer is used in this paper to denote a farmer who produces crops on a small piece of land mainly for household consumption. Any surplus to household requirements may be sold.
}

(C) 2012 The Clute Institute http://www.cluteinstitute.com/ 
economic growth prospects to most emerging economies (Akhavein et al., 2004: 245). Agriculture is the foundation of developing economies, including South Africa, whose population is growing at almost 2 percent per year. The population of 49 million in 2009 is expected to grow to 82 million by the year 2035. Food production or imports must more than double to feed the expanding population (World Wide Fund for Nature, undated). While it is necessary for all stakeholders to improve food production by smallholders, financing is observed to be a deterrent to the productivity of this sector.

South Africa has a developed banking sector that is comparable to those of developed countries (South African Reserve Bank, 2010). However, the smallholder farming sector has experienced slow growth in credit supply compared to other sectors of the economy. This is in spite of the strategic importance of the smallholder farmers in contributing to the reduction of unemployment, hunger and food insecurity. According to Olawale and Garwe (2010: 729), financial constraints are the principal obstacle to the growth of new SMEs. As Coetzee et al. (2002: 2) noted, agricultural finance in South Africa stands at the crossroads. They observed that both commercial banks and the Land Bank are no longer directing their financing activities toward smallholder farmers as much as they used to.

This paper contributes to the literature by tracking the supply of bank credit to smallholder farmers from 1986 to 2009. The aim of the paper is to determine whether smallholder farmers have sufficient access to bank credit required to support their production. Previous studies have attempted to explain the reasons for the poor performance of the smallholder farming sector (Mudhara, 2010: 4, and Fanadzo et al., 2010: 3515). However, while some studies acknowledged lack of access to finance as one of the reasons, none has particularly investigated the actual trends in the amount of credit channeled to smallholder farmers. Using time series data, this paper analyzes and reveals the state of financial support extended to smallholder farmers by South African banks and compares it with that offered to the large commercial sector and the non-farm domestic private sector. The results of the analysis validate assertions by Atkinson (2006: 378) that agricultural support has not received even remotely comparable funding. Atkinson (2006: 378) argues that with adequate funding, agricultural farming may do well.

\section{LITERATURE REVIEW}

Previous research has shown the significance of SMEs to foster growth prospects for both developed and developing economies. According to Beck and Demirguc-Kunt (2006: 2932), 'efforts targeted at the SME sector are often based on the premises that SMEs are the engine of growth, but market imperfections and institutional weaknesses impede their growth'. Challenges faced by non-farm SMEs are similar to those of smallholder farmers. While smallholder farmers are generally viewed as belonging to the SMEs category, a universally acceptable definition of a smallholder farmer has been contentious. South African agriculture consists of mainly two categories of farmers - subsistence (mainly rural areas) and large-scale commercial' ${ }^{2}$. According to Kirsten and Van Zyl (1998: 561) and Fanadzo et al. (2010: 3515), 'small-scale' in South Africa is often equated with backward, non-productive, non-commercial, subsistence agriculture that is found in rural areas. On the other hand, white farmers are generally perceived to be large-scale commercial farmers, who are modern and efficient, using advanced technology. Kirsten and Van Zyl (1998: 561) argue that these generalizations are a misrepresentation of the facts. They state that almost 25 percent of all farms in the 'white' commercial sector cover a land area smaller than 200 hectares and almost 5 percent are less than 10 hectares in size. While these farms are small, they are considered to be 'commercial' and large scale, although they should be correctly classified as smallholder farmers. Kirsten and Van Zyl (1998: 564) conclude by defining a small farmer as 'one whose scale of operation is too small to attract the provision of the services he/she needs to be able to significantly increase his/her productivity'. The difficulty in defining the term 'smallholder' is aptly articulated by Lahiff and Cousins (2005: 127):

There is no standard definition of a smallholder, but the term is generally used in the South African context for producers who are black and otherwise distinct from the dominant (and white dominated) large-scale commercial sector. No clear distinctions can be drawn between categories such as smallholder, small-scale, subsistence, communal or emergent.

\footnotetext{
${ }^{2}$ Generally, the term commercial farmer refers to one whose agricultural produce is entirely for sale. It differs from subsistence farmer whose produce is mainly for personal consumption and little is for sale. It is also defined by Statssa (1996:6) as "a farm producing agricultural products intended for the market, usually registered for value-added tax (VAT) and income tax.
} 
It is clear from the above definition that in the South African context, a smallholder farmer is viewed as a low-value producer. Smallholder farmers are constrained in one way or the other, such that seasonal output is compromised due to limited resources. This is unlike their commercial farmer counterpart who is seen as having sufficient resources to carry out farming business profitably. Smallholder farmers are categorized under SMEs due to their small size and scope of operation. For the purpose of this paper, a smallholder farmer is a farmer whose operations are classified as such by the Department of Agriculture, Forestry and Fisheries and classified as an SME by the Department of Trade and Industry.

Before 1994, the agricultural sector was characterized by the division between poor black smallholder farmers and the white large commercial farmers (Oettle et al., 1998). Typically, the legislative framework (the Native Authorities Act of 1951 and the Promotion of Bantu Self-Government Act No 46 of 1959) made it difficult for smallholder farmers producing from poorly-resourced rural areas to produce good yields competitively. Oettle et al. (1998: 6) argue that the 'highly dualistic' agricultural sector deliberately supported the white-dominated largescale farming, which received subsidized interest rates, unlike the smallholder farmers. This increased the availability of cheap credit and an increase in the appetite for credit by large-scale farmers. Since 1994, when the new constitution under the Government of National Unity was adopted, efforts were directed towards redressing the historical disequilibrium in the allocation of state resources to the development of agriculture across races (Coetzee et al., 2002).

The absence of finance to fund operations, acquire capital goods and meet working capital requirements has arguably been the largest challenge for most smallholder farmers in South Africa. In their study of the Wild Coast spatial development initiative (SDI) for small businesses in tourism and agriculture, Mitchell et al. (2008: 129) found that fewer households had bank loans in 2004 than in 1997. Instead, more households were taking loans from loan sharks rather than from banks. The Wild Coast SDI is located in the Eastern Cape, the second-poorest province in South Africa. These results are consistent with those of Varghese (2005: 318) who posits that moneylenders are the most prevalent informal lenders in India and in many developing countries because they have more information on smallholder farmers than banks do. He argues that some of the reasons why banks lend less to farmers are high borrower monitoring costs, a lack of collateral, and information constraints. Due to these problems, banks employ dynamic incentives, for example, not re-lending to defaulting borrowers. On the contrary, borrowers desire continuing access to bank loans. Those who default may do so due to a number of uncertainties that characterize the agricultural environment.

Results of Wynne and Lyne's (2003) study on poultry farmers in KwaZulu-Natal, a province of South Africa, indicate that enterprise growth rate is constrained by poor access to credit, high transaction costs and unreliable local markets. These results concur with those of an earlier study by Kalinda et al. (1998: 598) that suggest that agricultural credit is recognized as one of the means by which small-scale farmers can increase their capital base. They argue that government's dominance as a major credit source is largely a reflection of the reluctance of private financial institutions to invest in rural markets and agricultural production.

Availability of credit is important if inputs of good quality are to be available to farmers, especially smallscale producers (Kalinda et al., 1998: 590). Inputs such as improved seed, agrochemicals, and fertilizer require capital in the form of short-term credit. Available credit is often captured by larger producers while the poorer farmers may have little or no access to it because of institutional barriers. Poor farmers often have difficulty obtaining credit and financial institutions are typically biased against smallholders, particularly women farmers. This conclusion is firmly supported by Ani et al. (2009: 47) in their study of the contribution made by women to the production of groundnuts in Nigeria. They suggest that agricultural credit policy should be formulated to make credit facilities more accessible to women.

Balcombe et al. (2008: 1924-5), identified technical efficiency as an important factor in closing the rice yield gap in Bangladesh. Using the Data Envelope Analysis (DEA) double bootstrap as done by Simar and Wilson (2007: 33) to estimate and explain technical efficiency, they identified factors that enhance technical efficiency as being education, extension services, owner-operated farms, and bigger farms. This view is confirmed by Das et al. (2009: 76) who assert that there are three main factors that contribute to agricultural growth - agricultural inputs, technological change, and technical efficiency. The presence of these factors in the determination of agricultural 
output complicates the attempt to link agricultural output and the availability of bank credit per se. However, what is clear is that funding for all these factors is required in one form or another.

\section{METHODOLOGY}

We use time series data from 1986 to 2009 to examine bivariate data sets. The data are collected from the South African Reserve Bank (SARB), Statistics South Africa, and the Department of Agriculture, Forestry and Fisheries and are shown in Annexure A. The data series collected goes back to 1986 only because that is the year in which international economic sanctions were imposed on South Africa in relation to its apartheid policies and it was assumed that credit constraints began to be more onerous to marginalized sectors, such as the SME. In fact, following the imposition of sanctions, South Africa declared a debt standstill; i.e., repayment of foreign debt was suspended and foreign credit lines were suspended as a consequence. This observation is supported by Coetzee et al. (2002: 2) who posit that 'after 1985 a steady decline in real total farm debt occurred'. This was attributed to the decline in subsidies and a strict credit repayment programme followed by lenders.

Information on commercial bank credit to smallholder farmers could not be obtained because it does not form part of mandatory returns by banks to SARB. It was also not easy to access credit data directly from commercial banks, as they tend to be secretive about their practices in this regard. According to FinMark Trust (2006), only 2 percent of new SMEs are able to access bank credit. Furthermore, Foxcroft et al. (2002) reported that 75 percent of applications for bank credit by new SMEs are rejected. Hence, it follows that bank credit to smallholder farmers should be assumed to be a small proportion of banks' lending portfolios.

There are no national statistics that capture credit data specifically for smallholder farmers. The available farm credit data are provided by the Department of Agriculture, Forestry and Fisheries and Agricultural Statistics and includes farm credit provided by the Land Bank, commercial banks, agricultural cooperatives, Department of Agriculture, Forestry and Fisheries, other financial institutions, private persons, and other debt. To address the smallholder credit data deficiency, we assumed that a large proportion of credit to smallholder farmers largely emanates from cooperatives, the Department of Agriculture, Forestry and Fisheries, private persons and other sources, which include the Department of Rural Development and Land Reform. The Department of Agriculture, Forestry and Fisheries, in collaboration with the Department of Rural Development and Land Reform, provides post-settlement and production loans for new and upcoming farmers who meet the accessibility criteria (South Africa, Department of Agriculture, Forestry and Fisheries, 2010: 21). For the purposes of this study, credit from these sources is considered to be entirely destined for smallholder farmers ${ }^{3}$.

The paper acknowledges the government initiatives to reform the agricultural sector over the years. Such initiatives include the creation of the Land Bank whose mandate is to channel credit to both small and large farmers. Following poor corporate governance at the Land Bank (mismanagement, fraud and corruption), this mandate has not been carried out efficiently (Land Bank, 2010: 3). Consequently, the supply of credit to agriculture has declined significantly. It has almost dried up for smallholder farmers and is therefore not included in the computation of total credit to smallholders. This assessment is similar to that of Lahiff and Cousins (2005: 128) who argue that, like the Department of Agriculture, Forestry and Fisheries, the Land Bank has ignored targets for the inclusion of marginalized groups, but rather directed its support to 'emerging' farmers with access to credit.

Data for total credit extended to the non-farm private sector and GDP are obtained from the Statistics South Africa database. Data collected for total domestic credit to private sector excludes credit to both central and local governments, but includes households. The data were used for conducting a cross-sectional comparative analysis. The purpose of the comparative analysis is to determine the amount of credit extended to smallholder farmers as a proportion of total private sector credit, commercial farmers, and GDP. Finally, total farm debt includes debt provided by the Land Bank, commercial banks, agricultural cooperatives, Department of Agriculture, Forestry and

\footnotetext{
${ }^{3}$ This assumption must be treated with caution because these credit sources are also available to large-scale farmers. Furthermore, the assumption does not take into account that the Land Bank and commercial banks also lend a small proportion of their funds to smallholder farmers. Hence, farm credit to smallholder farmers referred to this article should be seen as an extrapolated approximation rather than fact.
} 
Fisheries, other financial institutions, private persons, and other debt (South Africa, Department of Agriculture, Forestry and Fisheries, Agricultural Statistics, 2011: 87). The Consumer Price Index (CPI) data used for this purpose were obtained from the SARB database. Farm debt figures are deflated by the index of all farming requisites to eliminate the effect of inflation. This approach was also applied by Coetzee et al. (2002: 3). The data sources used for this article are public data domains. The risk of using discrepant and biased data is thus mitigated. We use trend analysis to evaluate trends of credit provision to the farming sector for the period 1986 to 2009. To facilitate analysis and interpretation, the data cleaning was performed in a manner that makes it possible for analysis (Steyn et al., 1994: 219).

\section{DATA ANALYSIS AND DISCUSSION}

The trend of farm credit to GDP over the years is analyzed. Furthermore, credit received by the smallholder farmers is compared to that accessed by large-scale commercial farmers and the private sector. The proportion of smallholder credit to GDP is also analyzed.

\section{Ratio of Total Farm Credit to GDP}

The period 1986 to 1992 was characterized by a relatively high proportion of farm credit to GDP (Table 1). Farm credit averaged about 11 percent of GDP between 1986 and 1992. It plunged to below 2 percent from 1993 to 1997. From 1998 to 2009, the ratio recovered slightly and hovered at just over 2 percent of GDP. It is clear that the proportion of total farm credit to GDP fell significantly from 1993 to the 2000s. This happened when the contribution of agriculture to GDP largely remained unchanged; it averaged around 4 percent from 1986 to 1992 and barely 3 percent from 1993 to 2009 (South Africa, Department of Agriculture, Forestry and Fisheries, 2009: 20). The plunge of farm credit to GDP that started in 1993 could be partly attributed to the increased political uncertainty, which resulted in a decrease in the confidence level of the agricultural sector ${ }^{4}$.

Table 1: Total Farm Credit to GDP

\begin{tabular}{|c|c|c|c|c|c|}
\hline Year & $\begin{array}{c}\text { Total Farm } \\
\text { Debt/GDP } \\
\text { (percent) }\end{array}$ & Year & $\begin{array}{c}\text { Total Farm } \\
\text { Debt/GDP } \\
\text { (percent) }\end{array}$ & Year & $\begin{array}{c}\text { Total Farm } \\
\text { Debt/GDP } \\
\text { (percent) }\end{array}$ \\
\hline 1986 & 10.08 & 1994 & 1.65 & 2003 & 2.04 \\
\hline 1987 & 10.02 & 1995 & 1.71 & 2004 & 2.16 \\
\hline 1988 & 10.20 & 1996 & 1.71 & 2005 & 2.23 \\
\hline 1989 & 11.12 & 1997 & 1.86 & 2006 & 2.31 \\
\hline 1990 & 11.97 & 1998 & 2.03 & 2007 & 2.27 \\
\hline 1991 & 12.68 & 1999 & 2.22 & 2008 & 2.36 \\
\hline 1992 & 13.17 & 2000 & 2.29 & 2009 & 2.59 \\
\hline 1993 & 1.72 & 2001 & 2.31 & & \\
\hline
\end{tabular}

Source: South Africa. Department of Agriculture, Forestry and Fisheries, Abstract of Agricultural Statistics (2009)

\section{Ratio of Farm Credit to Total Private Sector Credit}

Figure 1 depicts the trend in the amount of credit extended to the agricultural sector in the two-and-half decades ending 2009. The agricultural sector received low supplies of credit relative to the total credit to all sectors. The ratio of farm credit to total private credit has been on a sharp decline since 1986. It declined from 45 percent in 1986 to a mere 5 percent by 2009. The downward trend is observed largely because banks and non-bank lenders channeled credit to mortgage financing due to high returns. For example, interest earned on mortgage bonds, which constituted 35 percent (1999: 35.6 percent) of total interest income in 2000, continued to be the largest component of income (SARB Annual Report, 2000: 52).

\footnotetext{
${ }^{4}$ Otherwise, further research is required to determine factors that led to the significant fall of farm credit as a proportion of GDP. 


\section{Ratio of Smallholder Farm Credit to GDP}

Figure 2 shows the trend of the ratio of smallholder farm credit to GDP. Before 1992, the ratio of smallholder farm credit to GDP was a small fraction below 6 percent. After 1992, the ratio nose-dived and barely breached the 1 percent mark as a proportion of GDP. This trend is attributed to low risk appetite by lenders to smallholder farmers which stagnated credit supply to the sector. During the same period, GDP growth was being recorded. This resulted in the reported downward trend in the relationship between smallholder farm credit and GDP.

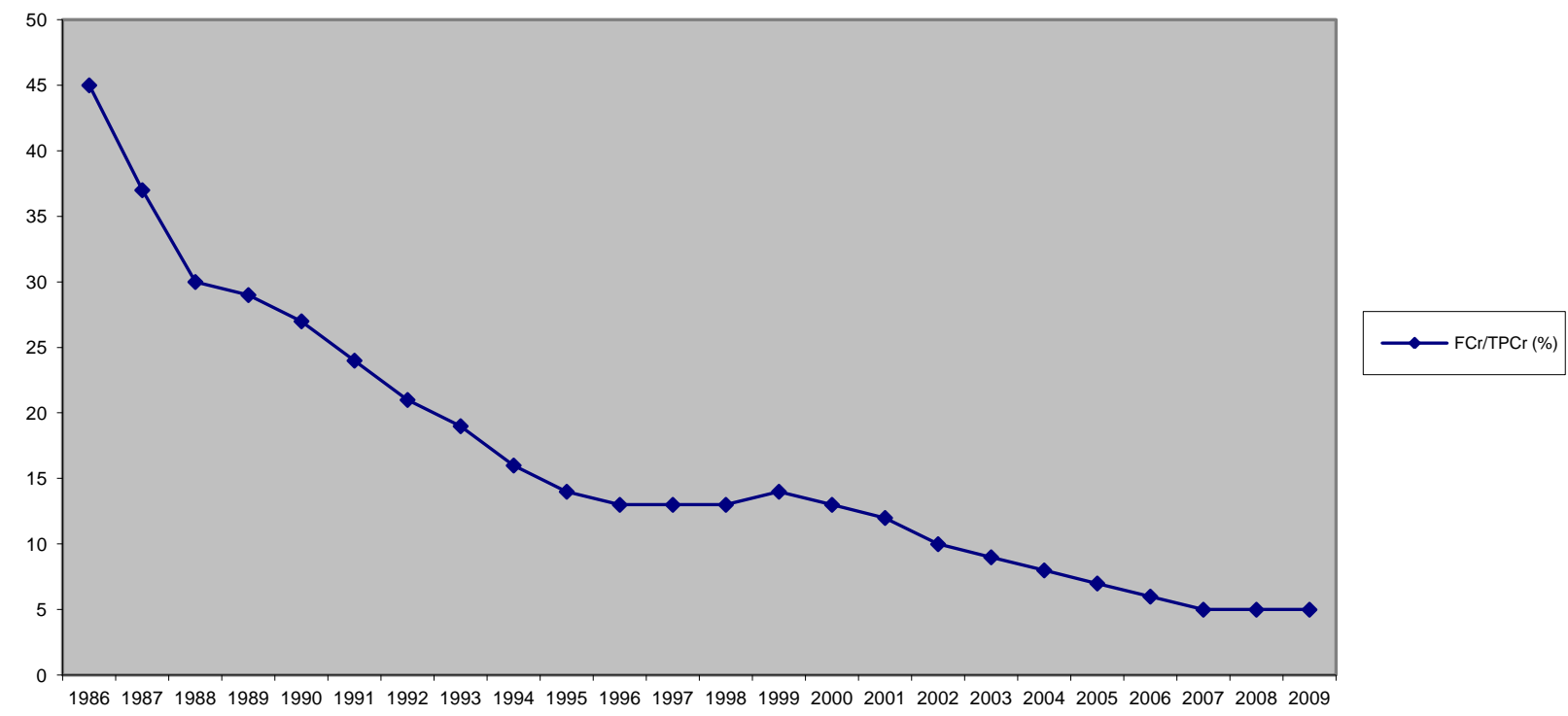

Figure 1: Ratio of Farm Credit to Total Private Credit (FCr/TPCr)

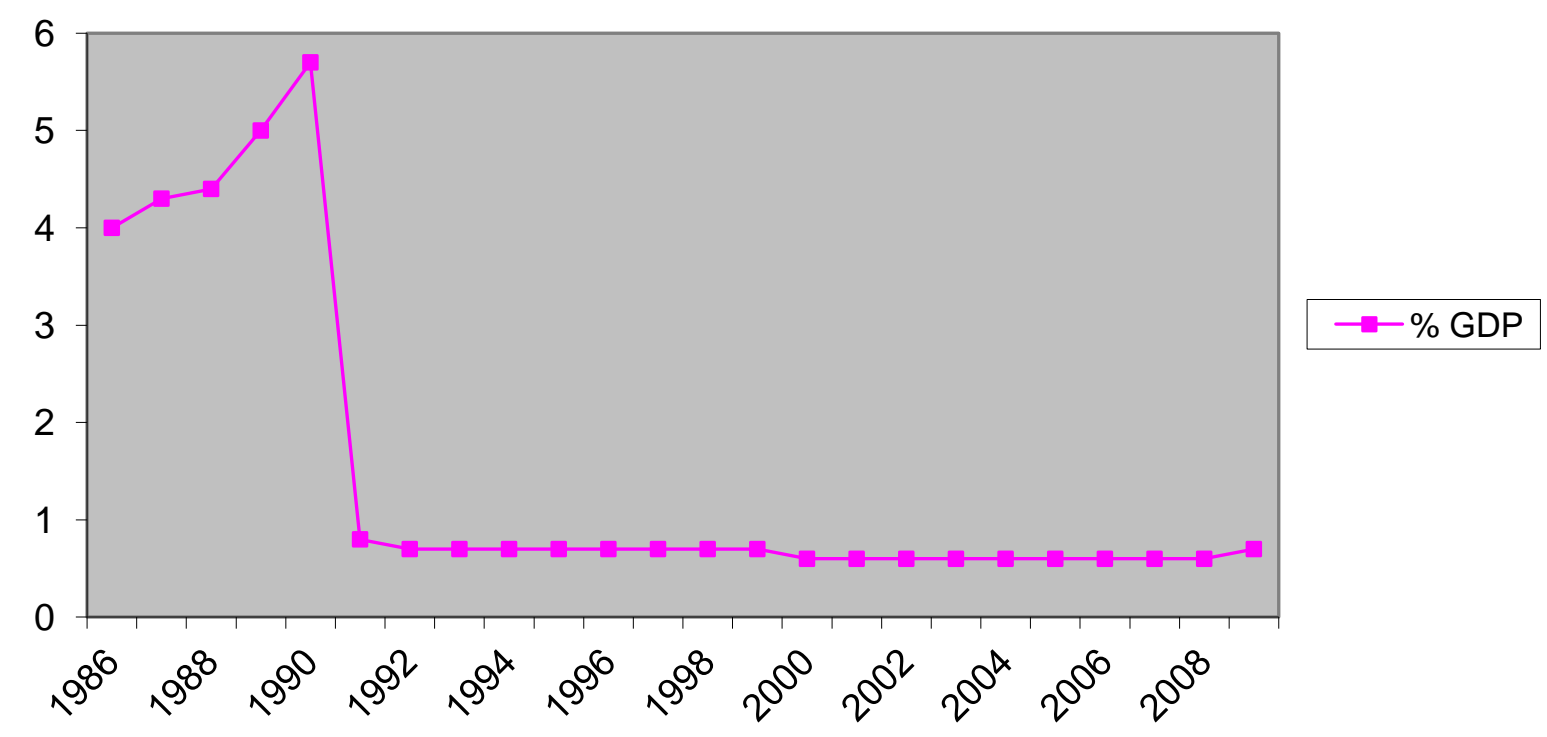

Figure 2: Ratio of Smallholder Farm Credit to GDP 


\section{The Trend of Smallholder Credit and Commercial Farm Credit}

A comparative analysis of total credit extended to smallholder farmers relative to that extended to commercial farmers (Figure 3) reveals that smallholder farmers receive far lower credit than their commercial counterparts. The smallholder credit supply lagged behind the commercial farming sector over the period under review. While credit to the large-scale sector shows an upward trend, credit to the smallholder sector has remained stagnant. The gap has continued to widen since 1986 with no sign that the two will ever converge. This is despite the complementary role the two subsectors should be playing in the attempt to alleviate hunger, poverty, and unemployment in South Africa. For example, the formal agricultural sector employs about 700,000 workers, including seasonal and contract, while the smallholder sector provides full-time employment to at least one million households (South Africa, Department of Agriculture, Forestry and Fisheries, 2010: 20). It is for this reason that the economic contribution of the smallholder farmers cannot be underestimated. The ability of commercial farmers to negotiate credit explains this trend. Commercial farmers have collateral required by lenders, superior farming skills, and technical know-how. It is because of lack of these attributes that smallholder farmers have received far less credit than commercial farmers.

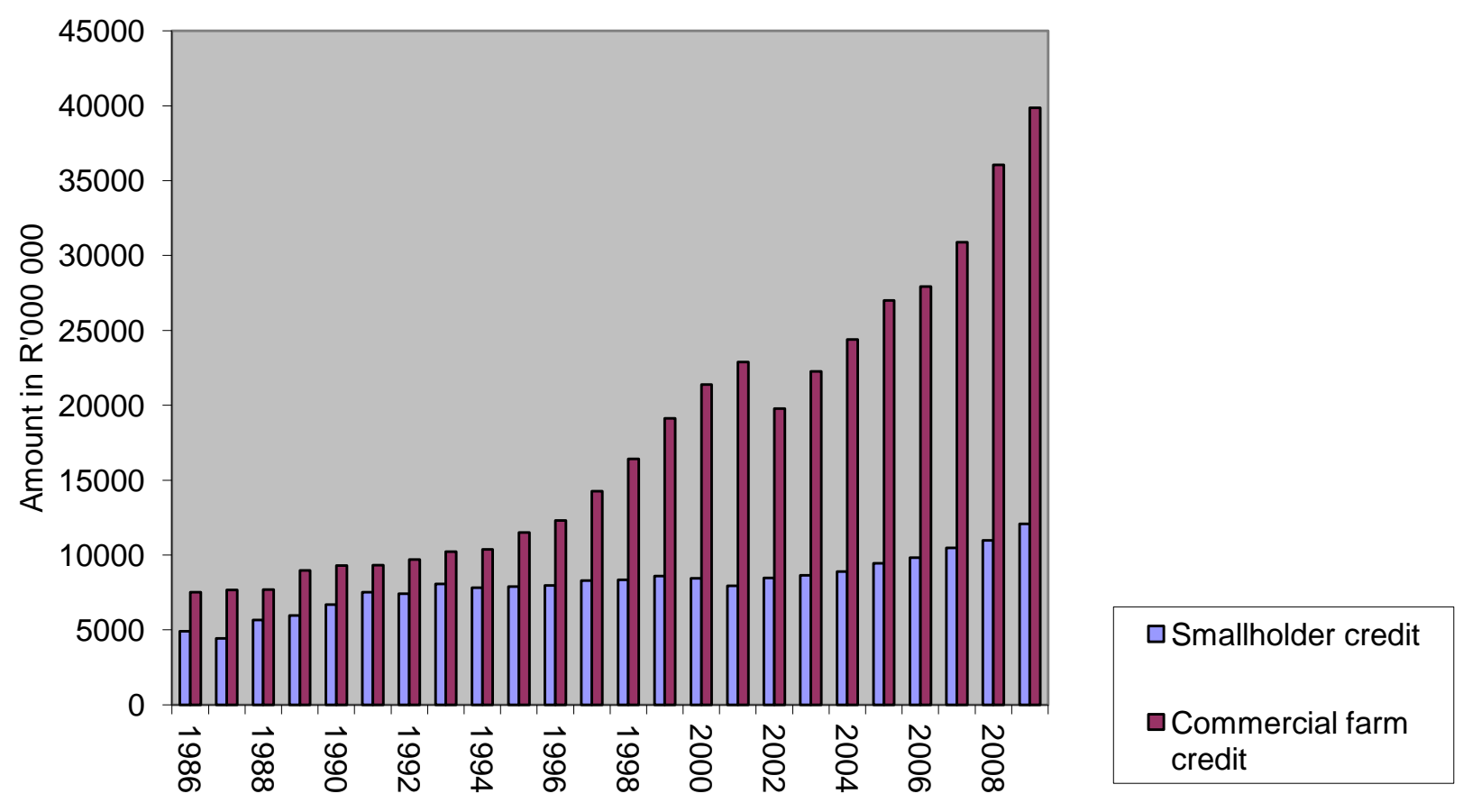

Figure 3: Trend of Smallholder Credit and Commercial Farm Credit (Rand 000's)

\section{Trends in Smallholder Credit to Total Domestic Private Sector Credit}

The ratio has continuously declined over the years indicating that smallholder farmers have had less access to credit than the domestic private sector (Figure 4). Similar results have been observed (Figure 1) on the total farm debt to total credit, excluding public sector credit. Figure 4 confirms this trend in the two decades to 2009. The ratio of smallholder credit to total domestic private sector credit declined from just under 18 percent in 1986 to about 1 percent in 2009. Since 1994, South Africa experienced unprecedented growth in money supply supported by domestic expenditure (SARB Annual Report, 2006: 13). The rising trend in total domestic credit continued through to 2005 before declining significantly in response to the restrictions of the National Credit Act. According to the SARB Annual Report (2005: 54-55), factors that contributed to this growth were monetary assets (which refer to legal tender in the Republic of South Africa, gold coin, bullion and non-South African currency holdings, and deposits with the South African Reserve Bank) which grew by 18.6 percent, from R32.3 billion as at December 
2004 to R38.3 billion as at 31 December, 2005. Other factors are growth in non-bank advances due to sharp growth in credit cards and increase in overdrafts and loans in 2004 due to low interest rates. For example, credit cards increased by R10 billion, to R31.2 billion (47.4 percent). The sharp growth in credit card was evidence of the growing borrowing demand by customers resulting from the lower interest rate environment in South Africa.

Clearly, it is seen from the above analysis that the amount of credit granted to smallholder farmers remained subdued in spite of a supportive interest rate regime. Ordinarily, it is expected that when interest rates fall, the propensity to borrow increases, ceteris paribus. That position is not evident here (Figure 4).

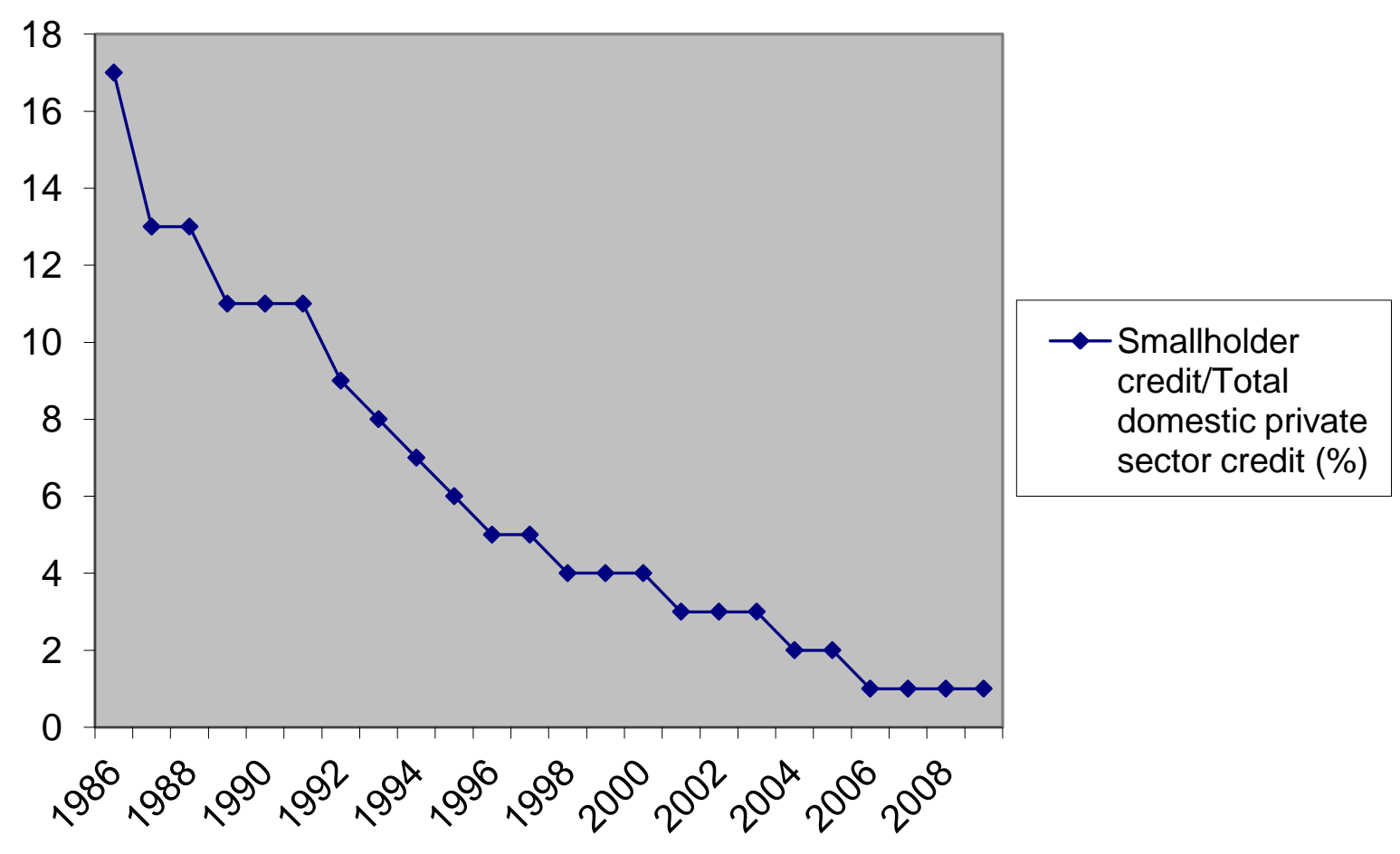

Figure 4: Ratio of Smallholder Credit to Total Domestic Private Sector Credit

\section{Trends in the Relationship between Smallholder Farm Credit, Commercial Farm Credit and Total Credit}

Total farm credit has remained a small proportion of the total domestic credit. In particular, credit to the smallholder sector has been very low during the period under review. Generally, the decline in lending rates, from 22 percent in 1998 to 12 percent in 2009, did not result in an increase in the supply of credit to smallholder farmers (Figure 5). However, it is noted that the years between 2004 and 2006 recorded an upswing in the supply of credit to the agricultural sector. This temporary shock was attributed to the positive real interest rates, suggesting that banks were willing to extent credit having been stimulated by the positive real returns. In particular, the real interest rate in 2004 was 10 percent when the inflation rate was 1 percent. 


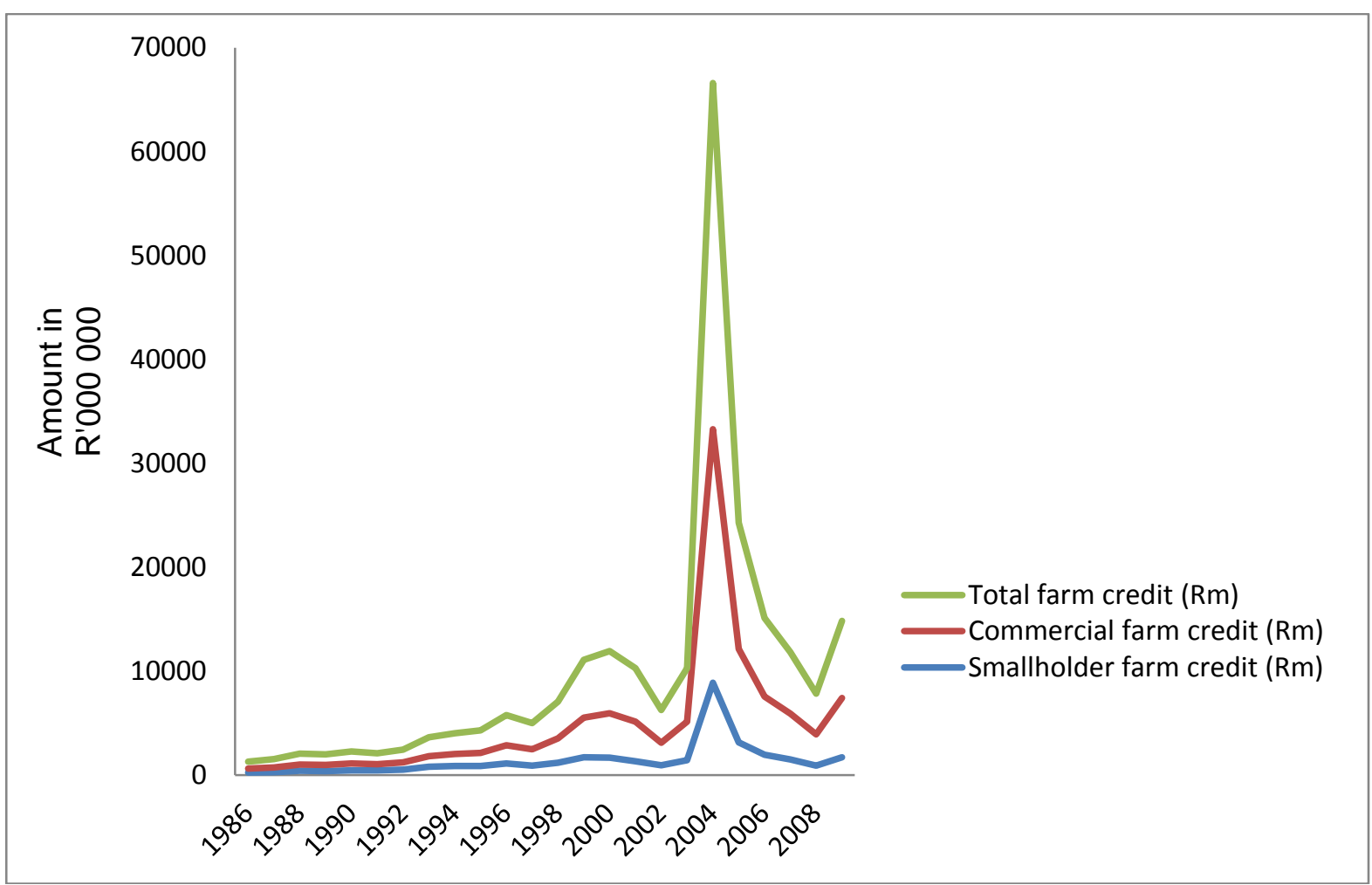

Figure 5: Trends in Real Smallholder Farm Credit, Commercial Farm Credit and Total Credit

\section{Trends in Lending Interest Rates}

The period 2003 to 2006 was characterized by a slump in inflation, recording a high of 5 percent (2006) and low of 1 percent in 2004. This led to a decline in interest rates. As expected, the amount of credit accessed by all sectors shored up significantly until 2006 before reverting to the same low levels that existed prior to 2004 after the interest rate shock. Figure 6 illustrates the interest rate trends in the period under review.

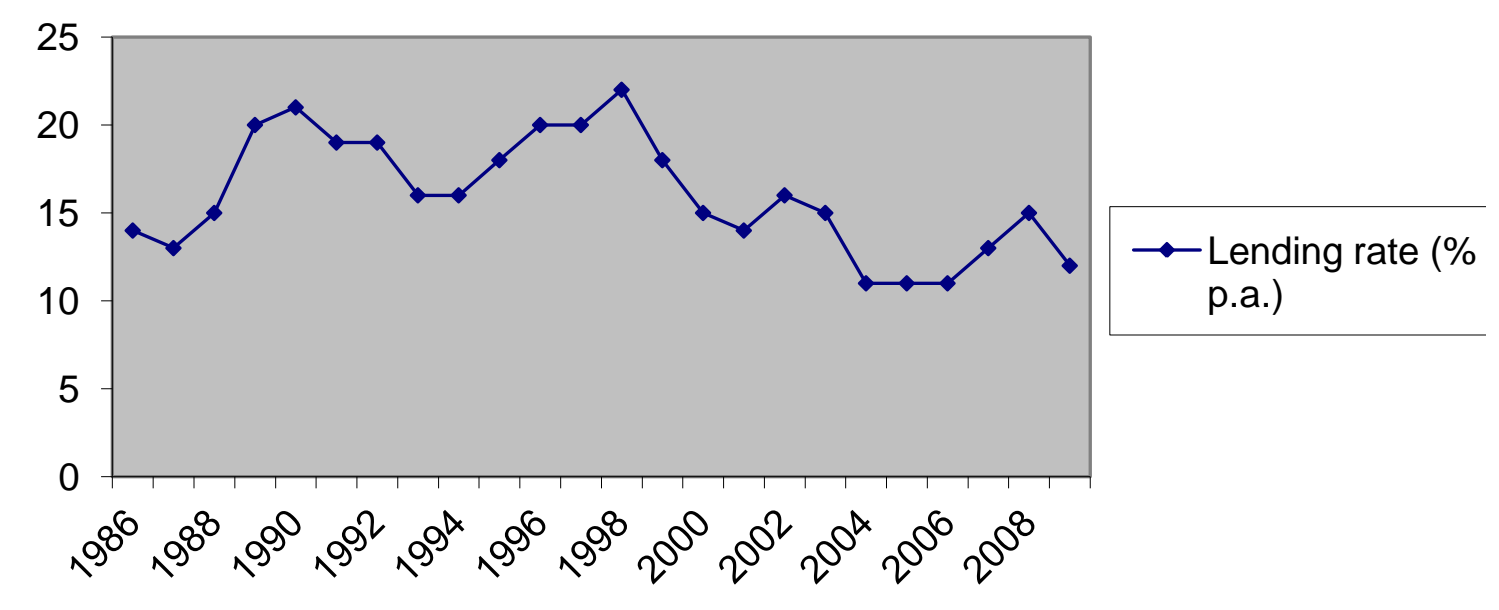

Figure 6: Trends in Lending Interest Rates 


\section{CONCLUSION}

The performance of smallholder farmers in South Africa has lagged behind the global reality and still falls below that of commercial farmers and the non-farm private sector. This situation is expected to continue in the future. Among other challenges, a lack of access to external financing, such as bank and other forms of credit, has been cited as one of the reasons for the poor performance. The aim of this paper was to track the trends in the supply of credit to the smallholder farming sector for the period 1986-2009.

Results of this research show that apart from the Department of Agriculture, Forestry and Fisheries, cooperatives and private individuals, credit providers, such as commercial banks, prefer lending to commercial farmers and the non-farm private sector because they are able to demonstrate viability and offer collateral. On the other hand, smallholder farmers generally lack these attributes and are deemed high risk. They are therefore unattractive to lenders. The results drawn from this analysis confirm what previous studies have reported. Although the Land Bank's mandate is to finance agriculture, its role in financing smallholder farmers still remains thin. The low credit extended to smallholder farmers is evident in the ratio of smallholder credit to total domestic private sector credit, which was found to be around 1 percent but below 2 percent. Similarly, the proportion of smallholder credit to commercial farm credit has remained constrained. The ratio of smallholder credit has been below 1 percent of GDP since 1992.

For South Africa to benefit from the potential of this financially marginalized agricultural sector, more financial support should be channeled to smallholder farmers. This will make it possible for the farmers to finance their requirements such as seed, farm equipment, and human capital development. With full government support through extension services, smallholder farmers have the potential to grow to become self-financing enterprises, contributing to the national reserves and the fiscus. It is also recommended that commercial banks be creative and develop credit products that are tailor-made for the smallholder farmers as derivative instruments are to corporate clients and commercial farmers.

It is clear from the results of this research that smallholder farmers receive the lowest amount of credit. The contribution of this paper is to inform policy in order to develop financial products that increase the amount of credit to smallholder farmers. The majority of South African youth are unemployed, poverty levels are escalating and the non-farm private sector is over-burdened with pressure to create employment. With increased access to credit, smallholder farmers have a role to play in ameliorating this situation. Based on the results of this research, it could be concluded that, despite the potential that smallholder farmers have to contribute to family income and national accounts, lending institutions are not committing themselves to financing smallholder farmers to levels where the smallholder farmers can improve output. This research was limited to the trends in the amount of credit to smallholder farmers. Further research is recommended which will inform commercial banks and other lenders on the management of default risk in portfolios of smallholder farmers in South Africa.

\section{ACKNOWLEDGEMENT}

The paper is based on an ongoing doctoral research project by the first author entitled: An Empirical Study of the Impact of Bank Credit on Agricultural Output in South Africa. Correspondence should be addressed to Joseph Chisasa at UNISA, Private Box 392, Pretoria 0003, e-mail: chisaj@unisa.ac.za, Telephone: +27 (12) 4294613.

\section{AUTHOR INFORMATION}

Mr. Joseph Chisasa is a Senior Lecturer in the Department of Finance, Risk Management and Banking of the University of South Africa. He holds a Master of Science Degree in Finance and Investment and Bachelor of Commerce Degree in Banking (Honours). He is a Certified Associate of the Institute of Bankers South Africa, Associate of the Institute of Bankers of Zimbabwe and an Associate Member of the Institute of Credit Management of South Africa. His research interests are in banking and credit risk management. E-mail: chisaj@unisa.ac.za. Corresponding author. 
Dr. Daniel Makina is Professor of Finance and Banking in the Department of Finance, Risk Management and Banking of the University of South Africa. He has published in recognized national and international journals that include: Applied Financial Economics, Applied Economics, International Business and Economics Research Journal, Journal of Developing Societies, Journal of Accounting and Finance Research, Business Review, African Development Review, African Finance Journal, among others. His research interests are in emerging financial markets, banking and migration issues related to financial development. Address: University of South Africa, PO. Box 392, Pretoria 0003, South Africa. E-mail: makind@unisa.ac.za

\section{REFERENCES}

1. Akhavein, J., Goldberg, L.G. and White, L.J. (2004). Small banks, small business, and relationships: an empirical study of lending to small farms, Journal of Financial Services Research 26(3): pp245-261.

2. Ani, A.O., Rahman, S.A. and Kwaghe, P.V. (2009). Economic contribution of women to groundnut production in rural area of Borno State, Nigeria, Asia-Pacific Journal of Rural Development XIX(2): pp4756.

3. Atkinson, D. (2006). Is there a case for support for smallholder agriculture? A response to Palmer and Sender, Journal of Contemporary African Studies 24(3): pp377-383.

4. Balcombe, K., Fraser, I., Latruffe, L., Rahman, M. and Smith, L. (2008). An application of the DEA double bootstrap to examine sources of efficiency in Bangladesh rice farming, Applied Economics 40: pp19191925.

5. Bandyopandhyay, A. (2007). Credit risk models for managing bank's agricultural loan portfolio. Accessed on 12 July 2010 http://mpra.ub.uni-muenchen.de/5358/

6. Beck, T. and Demirguc-Kunt, A. (2006). Small and medium-size enterprises: access to finance as a growth constraint, Journal of Banking and Finance 30: 2931-2943.

7. Coetzee, G., Meyser, F. and Adam, H. (2002). The financial position of South African Agriculture. Department of Agricultural Economics, Extension and Rural Development, University of Pretoria, Working Paper: 2002-01.

8. Das, A., Senapati, M. and John, J. (2009). Impact of agricultural credit on agriculture production: an empirical analysis in India. Reserve Bank of India Occasional Papers 30 (2): pp75-107.

9. Fanadzo, M., Chiduza, C. and Mnkeni, P.N.S. (2010). Overview of smallholder irrigation schemes in South Africa: relationship between farmer crop management practices and performance, African Journal of Agricultural Research 5(25): pp3514-3523.

10. FinMark Trust, (2006). FinScope Small Business Survey Report, Accessed on 13 September 2011 http://www.finmarktrust.org.za

11. Foxcroft, M., Wood, W., Kew, K., Herrington, M. and Segal, N. (2002). Global Entrepreneurship Monitor Report, Accessed on 13 September 2011 http://www.gbs.nct.ac.za/gbswebbb/userfiles/gemsouthafrica2000pdf

12. Kalinda, T.H., Shute, J.C. and Filson, G.C. (1998). Access to agricultural extension, credit and markets among small-scale farmers in southern Zambia, Development Southern Africa 15(4): pp589-608.

13. Katchova, L. and Barry, P. (2005). Credit risk models and agricultural lending, American Journal of Agricultural Economics 87(1): pp194-205.

14. Kirsten, J.F. and Van Zyl, J. (1998). Defining small-scale farmers in the South African context, Agrekon 37(4): pp560-571.

15. Lahiff, E. and Cousins, B. (2005). Smallholder agriculture and land reform in South Africa, Institute of Development Studies Bulletin 36(2): pp127-131.

16. Land Bank (2010) Annual Report, Accessed 21 August 2011 http://www.landbank.co.za/

17. Mitchell, S., Andersson, N., Ngxowa, N., and Merhi, M. (2008). A community-based impact assessment of the Wild Coast spatial development initiative, 1997-2004, Development Southern Africa 25(1): pp119-132.

18. Mudhara, M. (2010). Agrarian transformation in smallholder agriculture in South Africa: A diagnosis of bottlenecks and public policy options. Conference paper presented at 'Overcoming inequality and structural poverty in South Africa: Towards inclusive growth and development', Johannesburg, 20-22 September 2010. 
19. Oettle, N., Fakir, S., Wentzel, W., Giddings, S. and Whiteside, M. (1998). Encouraging sustainable smallholder agriculture in South Africa. Agricultural Services Reform in Southern Africa. Accessed 15 September 2011 http://www.eldis.org/vfile/upload/1/document/0708/DOC6491.pdf

20. Olawale, F. and Garwe, D. (2010). Obstacles to the growth of new SMEs in South Africa: A principal component analysis approach, African Journal of Business Management 4(5): pp729-738.

21. Sandrey, R. and Vink, N., (2008). Deregulation, trade reform and innovation in the South African agricultural sector, OECD Journal: General Papers 8(4): pp219-255.

22. Simar, L. and Wilson, P. (2007). Estimation and inference in two-stage, semi-parametric models of production process, Journal of Econometrics 136(1): pp31-64.

23. South Africa (2009), Department of Agriculture, Forestry and Fisheries, Abstract of agricultural statistics, Accessed 19 August 2011 http://www.daff.gov.za

24. South Africa (2010), Department of Agriculture, Forestry and Fisheries, Abstract of agricultural statistics, Accessed 19 August 2011 http://www.daff.gov.za

25. South Africa (2011), Department of Agriculture, Forestry and Fisheries, Abstract of agricultural statistics, Accessed 19 August 2011 http://www.daff.gov.za

26. South Africa (2007), Department of Transport. Annual report. Accessed 10 September 2011 http://www.transport.gov.za/siteimgs/Annualpercent20Reportpercent2007-08.pdf

27. South African Reserve Bank (2010) Annual report. Accessed 30 August 2011 http://www.resbank.co.za/Lists/Newspercent20andpercent20Publications/Attachments/4666/Annualpercent 20Reportpercent202010-11.pdf

28. Statistics South Africa, (2010), Concepts and definitions for Statistics South Africa Version 3 Accessed 26 October 2011 http://www.statssa.gov.za/inside_statssa/standardisation/Concepts_and_Definitions_percent20StatsSAV3.p df

29. Steyn, A.G.W., Smit, C.F. and Strasheim, C. (1994). Modern statistics in practice. Pretoria. Van Schaik Publishers.

30. Varghese, A. (2005). Bank-moneylender linkage as an alternative to bank competition in rural credit markets, Oxford Economic Papers 57(2): pp315-335

31. World Wide Fund for Nature (n.d.). 'Agriculture: Facts and trends, South Africa', Accessed 25 July 2011 http://assets.wwfza.panda.org/downloads/facts brochure mockup 04_b.pdf

32. Wynne, A.T. and Lyne, M.C. (2003). An empirical analysis of factors affecting the growth of small-scale poultry enterprises in KwaZulu-Natal, Development Southern Africa 20(5): pp563-577. 


\section{ANNEXURE A}

Credit Data Economic Indicators

\begin{tabular}{|c|c|c|c|c|c|c|c|c|}
\hline Year & $\begin{array}{c}\text { CPI } \\
\text { (percent) }\end{array}$ & $\begin{array}{c}\text { Lending } \\
\text { Rates } \\
\text { (percent) }\end{array}$ & $\begin{array}{c}\text { GDP } \\
\text { Nominal } \\
\text { Prices } \\
\end{array}$ & $\begin{array}{l}\text { Smallholder } \\
\text { Debt (Rm) }\end{array}$ & $\begin{array}{c}\text { Commercial } \\
\text { Farm Debt } \\
(\mathbf{R m}) \\
\end{array}$ & $\begin{array}{c}\text { Total Farm } \\
\text { Debt (Rm) }\end{array}$ & $\begin{array}{c}\text { Credit to } \\
\text { Domestic Private } \\
\text { Sector }(\mathbf{R m}) \\
\end{array}$ & $\begin{array}{c}\text { Total } \\
\text { Credit } \\
(\mathbf{R m})\end{array}$ \\
\hline 1986 & 19 & 14 & 123147 & 4907 & 7506 & 12412 & 27732 & 40144 \\
\hline 1987 & 16 & 13 & 125733 & 4428 & 7663 & 12880 & 34447 & 47327 \\
\hline 1988 & 13 & 15 & 131016 & 5665 & 7696 & 13361 & 44253 & 57614 \\
\hline 1989 & 15 & 20 & 134025 & 5951 & 8959 & 14910 & 51894 & 66804 \\
\hline 1990 & 14 & 21 & 133409 & 6678 & 9295 & 15973 & 59506 & 75479 \\
\hline 1991 & 15 & 19 & 132890 & 7515 & 9332 & 16847 & 70235 & 87082 \\
\hline 1992 & 14 & 19 & 130126 & 7425 & 9707 & 17132 & 82395 & 99527 \\
\hline 1993 & 10 & 16 & 1066215 & 8073 & 10214 & 18287 & 97014 & 115301 \\
\hline 1994 & 9 & 16 & 1100334 & 7808 & 10375 & 18184 & 114348 & 132532 \\
\hline 1995 & 9 & 18 & 1134445 & 7899 & 11497 & 19396 & 136267 & 155663 \\
\hline 1996 & 7 & 20 & 1183226 & 7956 & 12293 & 20250 & 159241 & 179491 \\
\hline 1997 & 9 & 20 & 1213990 & 8284 & 14267 & 22550 & 177442 & 199992 \\
\hline 1998 & 7 & 22 & 1220060 & 8341 & 16410 & 24751 & 195177 & 219928 \\
\hline 1999 & 5 & 18 & 1249341 & 8604 & 19125 & 27725 & 203185 & 230913 \\
\hline 2000 & 5 & 15 & 1301813 & 8445 & 21381 & 29826 & 226269 & 256095 \\
\hline 2001 & 6 & 14 & 1336962 & 7931 & 22895 & 30826 & 259162 & 289988 \\
\hline 2002 & 9 & 16 & 1386435 & 8462 & 19770 & 28232 & 286002 & 314234 \\
\hline 2003 & 6 & 15 & 1427322 & 8633 & 22259 & 30891 & 331842 & 362733 \\
\hline 2004 & -1 & 11 & 1492330 & 8882 & 24404 & 33286 & 412769 & 446055 \\
\hline 2005 & 2 & 11 & 1571082 & 9438 & 27006 & 36444 & 526647 & 563091 \\
\hline 2006 & 3 & 11 & 1659122 & 9832 & 27942 & 37774 & 684593 & 722367 \\
\hline 2007 & 6 & 13 & 1751499 & 10479 & 30900 & 41380 & 853819 & 895199 \\
\hline 2008 & 10 & 15 & 1814134 & 10982 & 36063 & 47044 & 966921 & 1013965 \\
\hline 2009 & 7 & 12 & 1783617 & 12076 & 39865 & 51942 & 1001946 & 1053888 \\
\hline
\end{tabular}

Source: Statssa, SARB and Department of Agriculture, Forestry and Fisheries 
NOTES 